\title{
PEMATAHAN DORMANSI BENIH AREN (Arenga pinnata (wurmb.) Merr.) PADA TINGKAT KEMASAKAN YANG BERBEDA MENGGUNAKAN METODE PERENDAMAN
}

\author{
Dormancy Breaking Sugar Palm (Arenga pinnata (Wurmb.) Merr.) Seeds at \\ Different Maturity Levels using Submersion Method)
}

\author{
Irwan Mahakam Lesmono Aji ${ }^{\star}$, Raden Sutriono, Arna Diansyah \\ Program Studi Kehutanan, Fakultas Pertanian, Universitas Mataram \\ Program Studi IImu Tanah, Fakultas Pertanian, Universitas Mataram \\ Jl. Pemuda, Dasan Agung Baru, Kec. Selaparang, Kota Matram, \\ Nusa Tenggara Barat 83114 \\ *Email : irwanmla@unram.ac.id
}

Direvisi : 16/10/2019, Diterbitkan 02/03/2020

\begin{abstract}
This study aims to find out the effect of submersion by using $1 \%$ acetic acid, $100 \%$ palm juice, and 100\% coconut water to break the dormancy of palm seeds at different maturity levels. The research was conducted in the Green House of Forestry Study Program, University of Mataram, using the experimental method with Complet Random Design (CRD) three factors. The first factor is the maturity level consists of 3 levels, the second factor is the submersion liquid substance consist of 3 levels, and the third factor is the period of submersion consist of 4 levels. The results of this study indicate that maturity rate gives significant influence on the following parameter i.e: percentage potency of seed germination, rotten seed, seed weight, seed moisture content, and embryo lenght, while seed dormancy parameter is not significant. The submersion factor significantly influenced on the following parameter i.e: seed weight, and seed water content, while the other parameters are not significant. The submersion period factor is significant only on seed moisture content and the embryo lenght, while the other parameters have no significant effect. While in all interactions between factors show no significant result on all parameters.
\end{abstract}

Keywords; aren; seed; submersion; dormancy breaking.

\begin{abstract}
ABSTRAK
Penelitian ini bertujuan untuk mengetahui bagaimana pengaruh perendaman menggunakan asam asetat $1 \%$, nira aren $100 \%$, dan air kelapa $100 \%$ terhadap pematahan dormansi benih aren pada tingkat kemasakan yang berbeda. Penelitian dilakukan di Green House Program Studi Kehutanan Universitas Mataram, menggunakan metode eksperimental dengan model Rancangan Acak Lengkap Faktorial (RALF) dengan tiga faktor. Faktor pertama adalah tingkat kemasakan terdiri dari 3 aras, faktor kedua adalah bahan perendaman dengan 3 aras, dan faktor ketiga adalah lama perendaman dengan 4 aras. Hasil dari penelitian ini menunjukkan tingkat kemasakan memberikan pengaruh signifikan terhadap parameter persentase potensi benih berkecambah, benih busuk, berat benih, kadar air benih, dan panjang embrio, sedangkan pada parameter benih dorman tidak signifikan. Faktor bahan perendaman berpengaruh signifikan terhadap parameter
\end{abstract}


berat benih, dan kadar air benih, sedangkan pada parameter lainnya tidak signifikan. Faktor lama perendaman hanya berpengaruh signifikan pada parameter kadar air benih, dan panjang embrio, sedangkan pada parameter lainnya tidak berpengaruh signifikan. Sementara pada semua interaksi antar faktor menunjukkan tidak signifikan terhadap semua parameter penelitian.

Kata kunci; aren; benih; perendaman; pematahan dormansi.

\section{PENDAHULUAN}

Aren (Arenga pinnata (Wurmb.) Merr.) merupakan tanaman asli dari Asia Tenggara. Di Indonesia tanaman ini hampir tersebar di seluruh wilayah Nusantara, khususnya daerah-daerah lembah perbukitan, baik di pulau kecil ataupun besar. Khususnya di Provinsi Nusa Tenggara Barat (NTB) tanaman ini tersebar dibeberapa tempat dan dikenal dengan beberapa nama daerah, seperti Lombok dan Bima dengan sebutan nao serta daerah Sumbawa dikenal dengan sebutan pola (Baharuddin \& Taskirawati, 2009).

Aren termasuk ke dalam jenis tanaman multifungsi atau MPTS (Multi Purpose Trees Species) karena hampir semua bagian tanaman ini mempunyai manfaat, baik secara ekologi, ekonomi, dan sosial. Tanaman ini di NTB, khususnya Pulau Lombok, sering dimanfaatkan sebagai penghasil nira dijadikan sebagai minuman (tuak manis), bahan baku gula merah, dan buah dijadikan kolang-kaling sebagai bahan campuran beraneka jenis makanan dan minuman, sedangkan manfaat lainnya sebagai hasil ikutan (ljuk, lidi, tali, dan bahan konstruksi). Namun, Lempang (2012) menjelaskan bahwa tanaman ini kurang mendapat perhatian untuk dikembangkan secara sungguh-sungguh oleh berbagai pihak. Padahal permintaan produk-produk yang dihasilkan tanaman ini, baik untuk kebutuhan ekspor maupun kebutuhan dalam negeri tetap diperlukan.

Tahun 2017, Asosiasi Aren Indonesia (AAI) menyatakan bahwa penyediaan gula merah di NTB minimal 1,5 ton/bulan gula merah. Permintaan ini tinggi jika dibandingkan dengan tingkat produksi di NTB hanya $600 \mathrm{~kg} / \mathrm{bulan}$ dengan kekurangan persediaan sebesar $9000 \mathrm{~kg} / \mathrm{bulan}$. Tingkat produksi ini rendah dikarenakan pola-pola produksi yang masih tradisional (Bul, 2017). Selain dari pola-pola produksi yang masih tradisional, diperlukan pula penyediaan bahan pokok dalam skala besar untuk memenuhi kebutuhan produksi dengan upaya pengembangan tanaman aren.

Pengembangan tanaman aren pada umumnya belum dibudidayakan secara massal. Petani masih mengandalkan tanaman yang tumbuh bergerombol dengan kondisi yang kurang optimal (Menper, 2014). Pembudidayaan aren di persemaian merupakan suatu cara untuk memproduksi bibit yang baik dan sehat. Namun, pada benih aren kendala yang sering dijumpai adalah masa dormansi yang lama, dikarenakan kulit benih yang keras. Sehingga, hal ini mengganggu kegiatan pembibitan. Pada tanaman aren, fase dormansi akan berakhir dengan munculnya lingkaran putih di samping benih, yang kemudian memanjang disebut dengan apokol. Marsiwi (2012) menyebutkan bahwa pada kondisi alami benih aren baru bisa berkecambah 5-6 bulan setelah disemai, bahkan Rozen et al. (2016) menyatakan bahwa benih aren dapat berkecambah sampai 1 tahun.

Teknologi dalam mematahkan dormansi benih aren sudah banyak dilakukan. Beberapa hasil penelitian menunjukkan bahwa perlakuan skarifikasi, dan perendaman menggunakan bahan kimia mampu memberikan hasil yang paling baik dibandingkan perlakuan lainnya. Namun, perlakuan skarifikasi sulit untuk diterapkan pada benih skala besar, begitupun dengan perlakuan bahan kimia dari segi ekonomis, harga yang mahal dan penerapannya yang sulit di masyarakat. 


\section{Pematahan Dormansi Benih Aren......(I.M. Lesmono Aji, dkk)}

Selain dari kulit benih aren yang keras, tingkat kemasakan benih juga mempengaruhi perkecambahan. Benih yang telah masak secara fisiologis telah memiliki cadangan makanan yang cukup dan pembentukan embrio sempurna untuk melakukan perkecambahan (Sutopo 2012). Selanjutnya Widyawati et al. (2009), menjelaskan bahwa semakin tua benih aren ternyata semakin rendah permeabilitasnya terhadap air meskipun kadar airnya semakin menurun, tetapi tidak bersifat impermeable sehingga ketika dikecambahkan proses imbibisi benih aren berlangsung sangat lambat antara lain disebabkan oleh meningkatnya kandungan lignin yang terdapat pada kulit benih.

Oleh karena itu, meskipun sejumlah penelitian telah dilakukan untuk mematahkan dormansi pada benih aren, baik secara fisik maupun kimia, tetapi kajian tentang sifat permeabilitas benih aren masih diperlukan untuk menemukan cara mempercepat pematahan dormansinya, khususnya pada penelitian ini, benih dengan tingkat kemasakan yang berbeda dilakukan perendaman menggunakan asam asetat $\left(\mathrm{CH}_{3} \mathrm{COOH}\right)$, nira aren dan air kelapa yang diharapkan dapat meningkatkan permeabilitas benih terhadap air agar mudah terimbibisinya air ke dalam benih. Dengan demikian, pentingnya penelitian ini dilakukan untuk melihat bagaimana pengaruh dari bahan perendaman tersebut pada tingkat kemasakan yang berbeda terhadap pematahan dormansi benih aren.

\section{METODE}

Penelitian ini dilaksanakan pada bulan Desember 2017-Mei 2018 dengan rincian waktusebagai berikut: ekstraksi benih selama 1 bulan terhitung dari Desember 2017Januari 2018, pelaksanaan percobaan terhitung dari Januari-Mei 2018 di Green House Program Studi Kehutanan Universitas Mataram, pengujian parameter penelitian pada bulan Mei 2017 di Laboratorium Silvikultur dan Teknologi Hasil Hutan Program Studi Kehutanan Universitas Mataram.

Alat dan bahan yang digunakan dalam penelitian ini adalah polybag ukuran $8 \mathrm{~cm} \times$ $22 \mathrm{~cm}$, alat tulis lengkap, solasi, ayakan, sarung tangan, wadah, karung, penggaris $30 \mathrm{~cm}$, paranet 1 lapis, Humidity Temperatur (HTC-2), Digital Lux Meter AS803, kertas label, bambu, tali rapiah, jangka sorong, timbangan analitik, gelas ukur $1000 \mathrm{ml}$, gelas beaker, alat penyiraman (gembor), kamera, tally sheet, oven, benih aren dengan tiga tingkat kemasakan, media tanah, air, larutan asam asetat $\left(\mathrm{CH}_{3} \mathrm{COOH}\right) 1 \% 1500 \mathrm{ml}$, nira aren $100 \% \pm 1500 \mathrm{ml}$, dan air kelapa $100 \% \pm 1500 \mathrm{ml}$.

Percobaan menggunakan Rancangan Acak Lengkap Faktorial (RALF) dengan tiga faktor dan diulang 3 kali. Faktor pertama tingkat kemasakan (K), faktor kedua bahan perendaman (B), dan faktor ketiga lama perendaman (L). Faktor tingkat kemasakan terdiri dari $\mathrm{k}_{1}$ (kemasakan M-3), $\mathrm{k}_{2}$ (kemasakan M-4), $\mathrm{k}_{3}$ (kemasakan M-5). Faktor bahan perendaman terdiri dari $b_{1}$ (asam asetat $1 \%$ ), $b_{2}$ (nira aren 100\%), dan $b_{3}$ (air kelapa $100 \%)$. Faktor lama perendaman terdiri dari $\mathrm{I}_{1}(0 \mathrm{jam}), \mathrm{I}_{2}(6 \mathrm{jam}), \mathrm{I}_{3}(12 \mathrm{jam})$, dan $\mathrm{I}_{3}(24$ jam).

Benih yang digunakan berasal dari Dusun Bentek, Desa Pemenang Barat, Kecamatan Pemenang, Kabupaten Lombok Utara. Buah aren yang diunduh terbagi kedalam tiga tingkat kemasakan dengan warna buah, yaitu buah yang berwarna hijau kekuningan (M-3), berwarna kuning (M-4) dan berwarna kuning kecokelatan (M-5). Buah yang diambil diusahakan pada pohon yang sama, apabila tidak mencukupi maka buah dapat pula diambil pada pohon yang berbeda dengan perawakan buah tidak terlalu berbeda. Beberapa benih diambil sebagai sampel untuk pengukuran kadar air untuk mengetahui tipe benih. Buah yang telah diunduh, diekstraksi sampai 1 bulan pada tempat yang lembap yakni ditimbun di dalam tanah, guna menghilangkan daging buah 
(mesokarp). Setelah benih diekstraksi maka benih dibersihkan dan dikeringanginkan selam \pm 3 jam.

Benih direndam sesuai dengan perlakuan yang diberikan. Setelah benih direndam, kemudian benih disemai pada polybag. Media tanam berasal dari tempat benih diunduh, dengan tekstur tanah liat lempung berpasir. Polybag disusun di Green House dengan naungan mencapai $86 \%$, suhu $28,36{ }^{\circ} \mathrm{C}$, dan kelembaban $77,22 \% \mathrm{RH}$. Pengamatan dilakukan mulai dari benih disemai sampai akhir penelitian. Adapun parameter yang diamati, meliputi persentase potensi benih berkecambah (\%), benih dorman (benih/polybag), benih busuk (benih/polybag), berat benih ( $\mathrm{g} / \mathrm{benih})$, kadar air benih (\%), dan panjang embrio $(\mathrm{mm})$.

Hasil penelitian dianalisis menggunakan Analisis Sidik Ragam (ANOVA) pada taraf signifikansi 5\%. Berdasarkan \%KK (Koefisien Keragaman) yang diperoleh, uji lankjut yang digunakan adalah uji lanjut DMRT pada taraf signifikansi 5\%.

\section{HASIL dan PEMBAHASAN}

\section{Kadar Air Benih}

Pada umumnya buah dengan tiga tingkat kemasakan, secara visual memiliki sifat fisik yang berbeda. Hal ini terlihat dari eksokarp pada M-3 berwarna hijau kekuningan, M-4 berwarna kuning merata, dan M-5 berwarna kuning kecokelatan (Usman, 2006cit. Saleh, 2002). Namun, setelah diekstraksi menjadi benih, maka secara visual akan terlihat endocarp yang sama antar ketiganya. Dalam hal ini, Usman (2006, cit. Saleh, 2002) menjelaskan bahwa perbedaan dari ketiga benih tersebut dapat dilihat dari endosperm dan embrio.

Tabel 1. Persentase Kadar Benih Aren (Arenga pinnata (Wurbm.) Merr.)

Table 1. Persentage of Sugar Palm (Arenga pinnata (Wurbm.) Merr.) Seeds Moisture Content)

\begin{tabular}{|c|c|c|c|c|}
\hline No & Tingkat Kemasakan & Berat Basah(g) & Berat Kering(g) & Kadar Air (\%) \\
\hline 1 & M-3 & 2,26 & 0,62 & 27,24 \\
\hline 2 & M-4 & 2,74 & 0,73 & 26,84 \\
\hline 3 & M-5 & 2,44 & 0,63 & 25,99 \\
\hline \multicolumn{2}{|c|}{ Rata-Rata } & 2,48 & 0,66 & 26,69 \\
\hline
\end{tabular}

Tabel 1, menunjukkan bahwa rata-rata kadar air benih pada setiap tingkat kemasakan berbeda-beda. Hasil perhitungan kadar air benih dari tiga tingkat kemasakan ini, rata-rata kadar air benih sebesar $26,69 \%$, sehingga benih aren digolongkan ke dalam benih rekalsitran. Widyawati et al. (2009) menjelaskan bahwa benih aren tergolong ke dalam rekalsitran karena kadar air benih yang relatif tinggi, yakni sebesar (25-30)\%. Selanjutnya secara fisiologi, Widyawati et al (2009) menjelaskan bahwa semakin tua benih aren, kadar airnya semakin turun dan penurunan kadar air ini membuat permeabilitas terhadap air semakin rendah.

Benih rekalsitran, jika terlalu lama disemaikan maka daya kecambah akan berkurang dan bahkan menimbulkan kematian pada benih (Mudiana, 2007). Namun, benih aren memiliki sifat dormansi dengan tipe dormansi exogenous, yakni dormansi yang disebabkan oleh kulit benih keras. Dengan adanya dormansi ini, benih aren dapat bertahan dalam jangka waktu yang cukup lama, sampai satu tahun bahkan lebih, sehingga masih dapat mempertahankan hidupnya walaupun viabilitasnya semakin menurun. 


\section{Pematahan Dormansi Benih Aren......(I.M. Lesmono Aji, dkk)}

Tabel 1 pula menunjukkan bahwa kadar air benih pada tingkat kemasakan hijau kekuningan (M-3) mempunyai kadar air benih paling tinggi dan yang terendah adalah kadar air benih pada tingkat kemasakan kuning kecokelatan (M-5). Dengan demikian, kadar air benih aren akan semakin menurun dengan semakin masak atau tuanya benih. Hal ini sesuai dengan apa yang dijelaskan oleh Usman (2006) dan Widyawati et al. (2009) yang menyatakan bahwa semakin tua benih aren maka kadar airnya semakin menurun. Widyawati et al. (2009) menjelaskan pula bahwa benih aren, walaupun memiliki kadar air yang rendah, tidak membuat absorbsi benih menjadi lebih tinggi dibandingkan benih yang kadar airnya tinggi.

\section{Analisis Pematahan Dormansi}

Dormansi benih merupakan salah satu kendala yang dialami jika mengadakan pembangunan persemaian. Walaupun dormansi ini merupakan cara benih dalam mempertahankan keberlangsungan hidupnya pada kondisi-kondisi yang kurang optimal, atau lingkungan yang kurang memungkinkan dalam melakukan metabolisme hidupnya, akan tetapi dormansi ini menjadi kendala dalam kemampuan benih untuk berkecambah dengan seragam.

Berdasarkan perlakuan perendaman benih terhadap pematahan dormansi benih aren pada tingkat kemasakan yang berbeda diperoleh data dan dilakukan analisis data menggunakan Analisis Sidik Ragam (ANOVA) terhadap parameter-parameter penelitian yang hasilnya dijabarkan pada Tabel 2.

Tabel 2. Hasil Analisis Sidik Ragam Parameter Pematahan Dormansi Benih Aren (Arenga pinnata (Wurbm.) Merr.)

Table 2. Result of Analysis of Variance on Parameter of Dormancy Breaking of Sugar Palm (Arenga pinnata (Wurbm.) Merr.) Seeds)

\begin{tabular}{|c|c|c|c|c|c|c|c|c|}
\hline \multirow{2}{*}{ No } & \multirow{2}{*}{ Parameter } & \multirow{2}{*}{$\mathrm{K}$} & \multirow{2}{*}{$\mathrm{B}$} & \multirow{2}{*}{$\mathrm{L}$} & \multicolumn{4}{|c|}{ Interaksi } \\
\hline & & & & & $\mathrm{K}^{\star} \mathrm{B}$ & $\mathrm{K}^{*} \mathrm{~L}$ & $B^{*} L$ & $K^{*} B^{\star} L$ \\
\hline 1 & Persentase Potensi Benih Berkecambah & S & ns & ns & ns & ns & ns & ns \\
\hline 2 & Benih Dorman & ns & ns & ns & ns & ns & ns & ns \\
\hline 3 & Benih Busuk & S & ns & ns & ns & ns & ns & ns \\
\hline 4 & Berat Benih & S & $S$ & ns & ns & ns & ns & ns \\
\hline 5 & Kadar Air Benih & S & S & $\mathrm{S}$ & ns & ns & ns & ns \\
\hline 6 & Panjang Embrio & s & ns & $\mathrm{s}$ & ns & ns & ns & ns \\
\hline
\end{tabular}

Berdasarkan hasil analisis sidik ragam pada Tabel 2, terdapat nilai-nilai yang signifikan pada faktor tunggal, sedangkan pada interaksi antar faktor tidak demikian. Nilai-nilai signifikan tersebut, pada sumber keberagaman tingkat kemasakan, signifikan terdapat pada semua parameter, kecuali pada benih dorman; sumber keberagaman bahan perendaman, signifikan terdapat pada parameter berat benih dan kadar air benih, sedangkan pada parameter yang lain tidak signifikan; sumber keberagaman lama perendaman, signifikan terdapat pada parameter kadar air benih dan panjang embrio, sedangkan pada parameter yang lain tidak signifikan; dan pada sumber keberagaman interaksi antar faktor tidak signifikan pada semua parameter.

\section{Persentase Potensi Benih Berkecambah}

Persentase potensi benih berkecambah merupakan potensi pendugaan suatu benih dalam kemampuannya untuk dapat berkecambah. Pendugaan tersebut, dilakukan dengan mengetahui jumlah benih dorman dan benih muncul apokol. Sementara benih yang sudah busuk keluar dari pengertian tersebut. Hal ini dikarenakan embrio atau bakal calon 
tanaman sudah busuk, sehingga tidak dapat melanjutkan perkembangannya menjadi kecambah normal.

Tabel 3. Hasil Uji DMRT Pengaruh Tingkat Kemasakan Terhadap Persentase Potensi Benih Berkecambah (\%)

Table 3. Result DMRT on The Effect of Maturity Levels on The Potency Percentage of Seed Germination (\%)

\begin{tabular}{ccc}
\hline Ranking & Kode Perlakuan & Nilai Rata-Rata \\
\hline 1 & $\mathrm{k}_{1}$ & $98,15^{\mathrm{a}}$ \\
2 & $\mathrm{k}_{2}$ & $94,45^{\mathrm{ab}}$ \\
3 & $\mathrm{k}_{3}$ & $88,89^{\mathrm{b}}$ \\
\hline
\end{tabular}

Keterangan: Nilai yang diikuti oleh huruf yang sama, menunjukkan tidak berbeda signifikan pada taraf signifikansi $5 \%$.

Tabel 3, menunjukkan bahwa dari masing-masing tingkat kemasakan memiliki potensi benih berkecambah yang berbeda. Potensi benih berkecambah yang paling tinggi terdapat pada tingkat kemasakan $\mathrm{k}_{1}(\mathrm{M}-3)$ sebesar $95,15 \%$, diikuti oleh tingkat kemasakan $\mathrm{k}_{2}(\mathrm{M}-4)$ sebesar $94,45 \%$, dan terendah pada tingkat kemasakan $k_{3}(M-5)$. Setelah dilakukan uji lanjut DMRT pada taraf signifikansi $5 \%$, perlakuan tingkat kemasakan $k_{1}$ dan $k_{2}$ menunjukkan tidak berbeda signifikan, serta $\mathrm{k}_{2}$ dan $\mathrm{k}_{3}$ pula tidak menunjukkan berbeda signifikan, sedangkan pada perlakuan kemasakan $k_{1}$ dan $k_{3}$ menunjukkan berbeda signifikan antar perlakuan.

Nilai signifikansi ini disebabkan oleh fisik benih yang berbeda pada tiap tingkat kemasakan, benih dengan tingkat kemasakan M-3 mempunyai fisik benih yang masih baik. Sementara pada perlakuan tingkat kemasakan $M-5$, beberapa benih memiliki guratan atau garis yang memanjang sejajar dari bagian pangkal benih sampai ujung benih, sedangkan pada benih tingkat kemasakan M-4 memiliki fisik antara M-3 dan M-5, yakni memiliki lebih sedikit guratan pada benih dibandingkan M-5. Dengan demikian, ketika terjadi imbibisi membuat benih mengembang dan menyebabkan guratan menjadi terbuka, sehingga benih menjadi busuk sebelum terpatahkan dormansinya.

Usman (2009) menyatakan bahwa potensi tumbuh maksimum (\%) pada benih aren dengan tingkat kemasakan M-3, M-4, dan M-5 tanpa skarifikasi mempunyai nilai yang berbeda-beda. Benih dengan tingkat kemasakan M-3 mempunyai potensi tumbuh maksimum yang paling tinggi 31,7\% dibandingkan dengan $M-4(25,0 \%)$, dan $M-5(28,3 \%)$. Hal ini menunjukkan bahwa benih dengan tingkat kemasakan M-3 mempunyai potensi tumbuh yang baik ketika tidak dilakukan skarifikasi pada kulit benih. Selanjutnya, Chaerani (2015) menyatakan pada benih aren dengan tingkat kemasakan M-5 ketika diskarifikasi, benih mengalami pembusukan sebesar 12\%, sedangkan pada benih yang tidak diskarifikasi, tidak terdapat benih busuk. Hal ini menyatakan bahwa ketika ada celah pada benih selain pori-pori benih, maka benih mudah mengalami pembusukan.

\section{Benih Dorman}

Dormansi merupakan suatu keadaan dimana benih yang sehat tidak dapat melakukan perkecambahan karena tidak terpenuhinya salah satu persyaratan dari dalam (tidak masaknya embrio) ataupun luar biji (faktor lingkungan) yang membantu dalam proses perkecambahan (Yudono, 2015). Istilah benih dorman dalam penelitian ini adalah benih yang tidak mampu berkecambah pada waktu tertentu yang telah ditetapkan, untuk mengevaluasi hasil dari perlakuan yang diberikan pada benih. Benih dorman pada aren dicirikan dengan endosperm benih yang masih utuh, berwarna putih dan keras, serta endosperm tidak membusuk. 
Hasil analisis sidik ragam pada Tabel 2, menunjukkan tidak signifikan pada semua sumber keberagaman, baik pada tingkat kemasakan, bahan perendaman, lama perendaman, dan semua interaksi antar faktor. Hasil ini menunjukkan bahwa perlakuan yang diberikan belum mampu memberikan perbedaan yang signifikan pada parameter benih dorman.

Benih tetap dalam keadaan dorman, apabila persyaratan benih untuk berkecambah tidak terpenuhi. Yudono (2015) menjelaskan bahwa, persyaratan benih akan berkecambah apabila benih mendapatkan sinar yang cukup (tidak semua jenis benih), suhu yang tepat, oksigen, dan air, dan lingkungan yang memungkinkan pertukaran gas. Disamping itu juga, tingkat kemasakan benih serta tidak ada hambatan dari benih sendiri, seperti kulit benih yang keras. Dengan demikian, syarat-syarat tersebut sangat menentukan keadaan benih, apakah benih akan berkecambah atau masih dalam keadaan dorman.

Benih dorman pada penelitian ini, terjadi karena perlakuan perendaman yang belum sesuai dengan kriteria benih aren untuk dapat melakukan proses perkecambahan benih dengan cepat. Hal ini dikarenakan, konsentrasi bahan dan lama perendaman yang belum tepat, dalam hal ini konsentrasi asam asetat yang masih rendah, dan jangka waktu perendaman pada air kelapa dan nira aren, yang masih rendah, sehingga perlu ditingkatkan.

\section{Benih Busuk}

Benih busuk keluar dari pengertian benih dorman, benih busuk adalah benih dengan embrio yang telah mati dan endosperm yang tidak utuh lagi karena mengalami pembusukan, sehingga benih tidak akan terpatahkan dormansinya dan berkecambah. Dalam penelitian ini, jika dalam waktu yang telah ditentukan, keadaan benih sesuai dengan kriteria yang telah dijabarkan, maka benih masuk ke dalam kategori benih busuk.

Benih busuk disebabkan oleh perlakuan yang kurang tepat dan mutu fisik benih yang disemaikan. Perendaman yang kurang tepat, dapat dilihat dari konsentrasi dan lama perendaman dari masing-masing bahan perendaman yang digunakan, kedua faktor ini harus sesuai antara satu sama lain. Sementara pada mutu fisik benih, dipengaruhi oleh kondisi benih pada setiap tingkat kemasakan.

Tabel 4. Hasil Uji DMRT Pengaruh Tingkat Kemasakan Terhadap Benih Busuk (benih/polybag)

Table 4. Result DMRT on the Effect of Maturity Levels on Rotten Seed (seed/polybag)

\begin{tabular}{ccl}
\hline Ranking & Kode Perlakuan & \multicolumn{1}{c}{ Nilai Rata-Rata } \\
\hline 1 & $\mathrm{k}_{3}$ & $0,33^{\mathrm{a}}$ \\
2 & $\mathrm{k}_{2}$ & $0,16^{\mathrm{ab}}$ \\
3 & $\mathrm{k}_{1}$ & $0,05^{\mathrm{b}}$ \\
\hline
\end{tabular}

Keterangan: Nilai yang diikuti oleh huruf yang sama, menunjukkan tidak berbeda signifikan pada taraf signifikansi $5 \%$.

Tabel 4, menunjukkan bahwa jumlah benih busuk pada setiap tingkat kemasakan memiliki nilai rata-rata yang berbeda. Tingkat kemasakan yang mempunyai nilai benih busuk yang rendah terdapat tingkat kemasakan $k_{1}$ (M-3) sebesar 0,06 benih/polybag. Sementara nilai rata-rata benih busuk tertinggi terdapat pada kemasakan $\mathrm{k}_{3}$ sebesar 0,33 benih/polybag. Setelah dilakukan uji lanjut DMRT pada taraf signifikansi $5 \%$, perlakuan tingkat kemasakan $\mathrm{k}_{1}$ dan $\mathrm{k}_{2}$ menunjukkan tidak berbeda signifikan, serta $\mathrm{k}_{2}$ dan $\mathrm{k}_{3}$ pula tidak menunjukkan perbedaan signifikan, sedangkan pada perlakuan kemasakan $\mathrm{k}_{1}$ dan $\mathrm{k}_{3}$ menunjukkan perbedaan signifikan antar perlakuan. 
Nilai-nilai yang signifikan disebabkan oleh fisik benih yang berbeda pada tiap tingkat kemasakan yang telah dijabarkan sebelumnya. Benih busuk akan terlihat endosperm yang berubah warna, awalnya putih menjadi sedikit cokelat. Endosperm ketika sudah keluar ke permukaan testa, maka akan meninggalkan warna putih ketika endosperm telah kering.

Chaerani (2015) menyatakan pada benih aren dengan tingkat kemasakan M-5 ketika diskarifikasi mengalami benih busuk sebanyak $12 \%$ sedangkan pada benih yang tidak diskarifikasi tidak ada benih yang busuk. Hal ini menyatakan bahwa ketika ada celah pada benih selain dari pori-pori benih akan mudah terjadinya pembusukan benih dan keluarnya endosperm sebelum benih mengalami perkecambahan.

\section{Berat Benih}

Berat benih menunjukkan bobot basah benih utuh dalam jangka waktu tertentu yang telah ditetapkan. Perhitungan bobot basah merupakan akibat dari terimbibisi air ke dalam benih, yang dipengaruhi oleh perlakuan terhadap benih yang diuji. Berat benih merupakan bagian dari parameter yang menunjukkan bahwa suatu benih ketika diberikan perlakuan tertentu, maka akan memberikan hasil dengan penambahan berat bobot basah benih.

Tabel 5. Hasil Uji DMRT Pengaruh Tingkat Kemasakan Terhadap Berat Benih (g/benih) Table 5. Result DMRT on the Effect of Maturity Levels on Seed weight (g/seed)

\begin{tabular}{ccc}
\hline Ranking & Kode Perlakuan & Nilai Rata-Rata \\
\hline 1 & $\mathrm{k}_{3}$ & $3,24^{\mathrm{a}}$ \\
2 & $\mathrm{k}_{2}$ & $3,19^{\mathrm{a}}$ \\
3 & $\mathrm{k}_{1}$ & $2,71^{\mathrm{b}}$
\end{tabular}

Keterangan: Nilai yang diikuti oleh huruf yang sama, menunjukkan tidak berbeda signifikan pada taraf signifikansi $5 \%$.

Tabel 5, menunjukkan bahwa berat benih pada setiap tingkat kemasakan memiliki nilai rata-rata yang berbeda. Tingkat kemasakan yang mempunyai nilai berat benih yang tertinggi terdapat tingkat kemasakan $\mathrm{k}_{3}(\mathrm{M}-5)$ sebesar 3,24 g/benih. Sementara nilai ratarata berat benih terendah terdapat pada kemasakan $k_{3}$ sebesar 2,71 g/benih. Setelah dilakukan uji lanjut DMRT pada taraf signifikansi $5 \%$, perlakuan tingkat kemasakan $\mathrm{k}_{2}$ dan $\mathrm{k}_{3}$ menunjukkan tidak berbeda signifikan, sementara keduanya berbeda signifikan dengan $k_{1}$.

Hasil ini pula diperkuat oleh Widyawati et al. (2009) menyatakan bahwa berat benih semakin meningkat dengan bertambahnya umur biji aren, namun pada kadar air semakin berkurang dengan bertambahnya umur biji aren. Pada umur biji aren pada 12 BSA mempunyai berat segar sebesar 2,43 gram dengan kadar air benih sebesar $89,77 \%$ sementara pada biji dengan umur 28 BSA mempunyai berat segar sebesar 4,58 gram dengan kadar air benih sebesar $26,43 \%$.

Endosperm pada benih aren mengandung karbohidrat, protein, lemak dan mineral yang berfungsi sebagai bahan baku dan energi untuk melakukan perkecambahan. Sutopo (2012), menduga bahwa benih yang mempunyai berat atau ukuran yang besar mengandung cadangan makanan yang lebih banyak dibandingkan dengan benih kecil, kemungkinan pula embrionya lebih besar. Ukuran benih menunjukkan korelasi positif terhadap kandungan protein pada benih sorghum, makin besar/berat ukuran benih maka kandungan proteinnya meningkat pula (Sutopo, 2009 cit. Worker \& Ruckman 1968).

Tabel 6. Hasil Uji DMRT Pengaruh Bahan Perendaman Terhadap Berat Benih ( $\mathrm{g} / \mathrm{benih}$ ) Table 6. Result DMRT on the Effect of Submersion Liquid Substance on Seed Weight (g/seed)

Ranking Kode Perlakuan $\quad$ Nilai Rata-Rata




\begin{tabular}{lll}
\hline 1 & $\mathrm{~b}_{1}$ & $3,12^{\mathrm{a}}$ \\
2 & $\mathrm{~b}_{3}$ & $3,12^{\mathrm{a}}$ \\
3 & $\mathrm{~b}_{2}$ & $2,91^{\mathrm{b}}$ \\
\hline
\end{tabular}

Keterangan: Nilai yang diikuti oleh huruf yang sama, menunjukkan tidak berbeda signifikan pada taraf signifikansi $5 \%$.

Tabel 6 , menunjukkan bahwa bahan perendaman $b_{1}$ dan $b_{3}$ memiliki nilai berat benih paling tinggi 3,12 $\mathrm{g} / \mathrm{benih}$, dan terendah pada $b_{2}$ dengan nilai sebesar 2,91 $\mathrm{g} / \mathrm{benih}$. Setelah dilakukan uji lanjut DMRT pada taraf signifikansi $5 \%$, perlakuan bahan perendaman $b_{1}$ dan $b_{3}$ menunjukkan tidak berbeda signifikan, sementara keduanya berbeda signifikan dengan $b_{2}$.

Nilai berat benih tersebut menunjukkan bahwa benih dengan bahan perendaman menggunakan $b_{1}$ (asam asetat $1 \%$ ) dan $b_{3}$ (air kelapa $100 \%$ ) mempunyai nilai yang paling tinggi, dan terendah pada $b_{2}$ (nira aren $100 \%$ ). Perbedaan ini, dikarenakan kemampuan bahan perendaman yang berbeda. Bahan dengan kemampuan lebih tinggi, membuat air lebih cepat terimbibisi ke dalam benih yang akan mempengaruhi berat, karena pertambahan kandungan air di dalam benih. Kandungan air ini akan digunakan untuk kebutuhan proses perkecambahan. Sehingga, nantinya kadar air akan berkurang pada waktu tertentu, karena digunakan untuk proses perombakan kandungan cadangan makanan di dalam benih.

Bahan perendaman $b_{1}$, memiliki nilai berat benih paling tinggi karena senyawa yang dimiliki oleh asam asetat yang bersifat korosif sehingga kulit benih lebih cepat lunak dibandingkan bahan perendaman lainnya. Bahan perendaman $b_{3}$ memiliki nilai yang hampir atau sama dengan $b_{1}$, karena air kelapa memiliki asam organik berupa asam askorbat sehingga diduga kemampuannya hampir sama dengan $b_{1}$. Sementara pada $b_{2}$ senyawa yang terkandung pada nira aren segar masih dalam bentuk sukrosa, yakni 12,30 $\mathrm{gr} / 100 \mathrm{ml}$ sampai $17,40 \mathrm{gr} / 100 \mathrm{ml}$ (Ichsan, 2014) dan belum begitu banyak mengalami perubahan menjadi alkohol.

Ichsan (2014), menyatakan bahwa kadar alkohol pada nira aren dengan waktu 1 hari atau 24 jam pada suhu ruang, akan mengandung alkohol sebesar $31 \%$ dan akan klimaks pada 7 hari sebesar $50 \%$ dan kemudian akan mengalami penurunan setelah hari ke-7 yang disebabkan oleh fermentasi lanjutan alkohol menjadi asam asetat. Asam asetat yang terbentuk pada hari ke-1 atau 24 jam pada nira aren pada suhu ruang adalah $0,18 \%$. Sehingga diduga pada perlakuan pada $b_{2}$ ini yang berperan dominan dalam melakukan pengikisan kulit benih aren adalah alkohol yang terdapat pada fermentasi nira aren.

\section{Kadar Air Benih}

Kadar air benih yang dimaksud dalam penelitian ini adalah kandungan air yang dimiliki oleh benih akibat dari terimbibisi air ke dalam benih, setelah diberikan perlakuan perendaman. Kadar air benih menjadi parameter yang penting, untuk melihat sejauh mana perkembangan benih dalam proses pematahan dormansi atau perkecambahan. Selanjutnya, Lensari (2009, cit. Byrd, 1968) dan Sutopo (2012) menjelaskan bahwa kadar air digunakan untuk proses perombakan cadangan makanan yang terdapat dalam benih. Air digunakan untuk mengaktifkan enzim-enzim yang berperan dalam proses perombakan, seperti enzim amilase untuk merombak karbohidrat menjadi glukosa, enzim lipase untuk merombak lemak menjadi asam lemak dan gliserol, serta enzim protase untuk merombak protein menjadi asam amino.

Widyawati et al. (2009) menjelaskan bahwa benih tersusun atas kulit benih (testa), bagian penyimpan cadangan makanan (endosperm), dan embrio. Masing-masing bagian benih ini, memiliki porsi kadar air yang berbeda-beda. Hasil penelitian Widyawati et al. 
(2009), menyatakan persen kadar air tertinggi terdapat di bagian embrio, kemudian endosperm benih, benih utuh, dan terendah terdapat pada kulit benih. Hal ini dikarenakan bagian seluruh embrio benih tersusun oleh sel-sel hidup yang aktif dan banyak mengandung air untuk mempertahankan hidupnya. Jaringan testa merupakan jaringan mati, sedangkan jaringan endosperm sebagian selnya bersifat hidup.

Tabel 7. Hasil Uji DMRT Pengaruh Tingkat Kemasakan Terhadap Kadar Air Benih (\%)

Table 7. Result DMRT on the Effect of Maturity Levels on Seed Moisture Content (\%)

\begin{tabular}{ccc}
\hline Ranking & Kode Perlakuan & Nilai Rata-Rata \\
\hline 1 & $\mathrm{k}_{1}$ & $32,59^{\mathrm{a}}$ \\
2 & $\mathrm{k}_{3}$ & $31,97^{\mathrm{ab}}$ \\
3 & $\mathrm{k}_{2}$ & $30,71^{\mathrm{b}}$ \\
\hline
\end{tabular}

Keterangan: Nilai yang diikuti oleh huruf yang sama, menunjukkan tidak berbeda signifikan pada taraf signifikansi $5 \%$.

Tabel 7, menunjukkan bahwa kadar air benih pada setiap tingkat kemasakan memiliki nilai rata-rata yang berbeda. Tingkat kemasakan yang mempunyai nilai kadar air benih yang tertinggi terdapat tingkat kemasakan $\mathrm{k}_{1}$ (M-3) sebesar $32,59 \%$. Sementara nilai ratarata berat benih terendah terdapat pada kemasakan $\mathrm{k}_{2}$ sebesar $30,72 \%$. Setelah dilakukan uji lanjut DMRT pada taraf signifikansi $5 \%$, perlakuan tingkat kemasakan $\mathrm{k}_{1}$ dengan $\mathrm{k}_{3}$ berbeda signifikan, dan $k_{1}$ pun berbeda signifikan dengan $k_{2}$, sementara $k_{2}$ tidak menunjukkan beda signifikan dengan $\mathrm{k}_{3}$.

Benih aren kemasakan $\mathrm{k}_{1}$ mempunyai nilai kadar air yang paling tinggi, menunjukkan bahwa $\mathrm{k}_{1}$ mempunyai permeabilitas yang paling tinggi dibandingkan $\mathrm{k}_{2}$ dan $\mathrm{k}_{3}$. Secara umum berdasarkan penelitian Widyawati, et al.(2009) perendaman benih pada berbagai umur biji di dalam air biasa selama 24 jam, menyatakan bahwa pertambahan berat benih semakin menurun dengan bertambahnya umur biji aren. Begitupun dalam penelitian yang lain, Widyawati et al. (2009, cit. Shepard \& Naylor, 1996) menyebutkan bahwa pada benih sorgum (Sorghum bicolor (L.) Moench) impermeabilitas kulit benih berkembang sesuai dengan kemasakan benih. Benih yang dipanen sebelum mencapai berat kering maksimum ternyata lebih permeable terhadap air.

Pada $\mathrm{k}_{3}$ nilai rata-rata kadar air benih lebih tinggi dibandingkan $\mathrm{k}_{2}$. Hal ini berlawanan dengan pernyataan yang dijelaskan sebelumnya, bahwa impermeabilitas kulit benih berkembang sesuai dengan kemasakan benih. Namun demikian, berdasarkan uji lanjut DMRT $k_{2}$ tidak berbeda signifikan dengan $k_{3}$. Perbedaan nilai rata-rata kedua tingkat kemasakan tersebut, diduga karena ukuran dan ruang untuk kadar air benih $\mathrm{k}_{3}$ lebih besar dibandingkan $\mathrm{k}_{2}$.

Widyawati et al. (2009) menjelaskan bahwa secara umum semakin rendah kadar air benih, jika direndam dalam air maka kekuatan menarik air (driving force) masuk ke dalam benih semakin besar. Tetapi yang terjadi pada benih aren ternyata bahwa semakin tua benih, imbibisinya semakin rendah meskipun kadar airnya semakin turun. Hal ini menunjukkan bahwa bukan kadar air benih yang mengendalikan imbibisi melainkan sifat kulit benih tersebut.

Tabel 8. Hasil Uji DMRT Pengaruh Bahan Perendaman Terhadap Kadar Air Benih (\%) Table 8. Result DMRT on the Effect of Submersion Liquid Substance on Seed Moisture Content (\%)

\begin{tabular}{ccc}
\hline Ranking & Kode Perlakuan & Nilai Rata-Rata \\
\hline 1 & $\mathrm{~b}_{3}$ & $32,98^{\mathrm{a}}$ \\
2 & $\mathrm{~b}_{2}$ & $31,50^{\mathrm{ab}}$ \\
3 & $\mathrm{~b}_{1}$ & $30,79^{\mathrm{b}}$ \\
\hline
\end{tabular}


Keterangan: Nilai yang diikuti oleh huruf yang sama, menunjukkan tidak berbeda signifikan pada taraf signifikansi $5 \%$.

Tabel 8, menunjukkan bahwa bahan perendaman $b_{3}$ memiliki nilai kadar air benih paling tinggi $32,99 \%$, diikuti oleh $b_{2}(31,51 \%)$ dan terendah pada $b_{1}$ dengan nilai sebesar $30,79 \%$. Setelah dilakukan uji lanjut DMRT pada taraf signifikansi $5 \%$, perlakuan bahan perendaman $b_{1}$ dengan $b_{2}$ menunjukkan tidak berbeda signifikan, dan $b_{2}$ pun tidak berbeda signifikan dengan $b_{3}$, sementara antara $b_{1}$ dan $b_{3}$ menunjukkan berbeda signifikan. Pengaruh dari hasil ini menunjukkan tidak jauh berbeda dengan parameter-parameter sebelumnya, umumnya dipengaruhi oleh kemampuan dari masing-masing bahan untuk membuat kulit benih menjadi permeabel terhadap air. Dalam hal ini bahan $b_{3}$ mempunyai kadar air yang paling tinggi.

Perendaman benih malapari menggunakan air kelapa 100\% selama 6 jam menghasilkan persentase daya kecambah tertinggi $90 \%$, dibandingkan dengan perendaman air biasa selama 24 jam sebesar 87\% (Suita \& Syamsuwida, 2015). Hasil ini menunjukkan bahwa air kelapa memberikan hasil yang optimal dibandingkan perlakuan lainnya.

Tabel 9. Hasil Uji DMRT Pengaruh Bahan Perendaman Terhadap Kadar Air Benih (\%)

Table 9. DMRT on the Effect of Submersion Liquid Substance on Seed Moisture Content (\%)

\begin{tabular}{ccc} 
Ranking & Kode Perlakuan & Nilai Rata-Rata \\
\hline 1 & $\mathrm{I}_{1}$ & $32,97^{\mathrm{a}}$ \\
2 & $\mathrm{I}_{3}$ & $32,47^{\mathrm{a}}$ \\
3 & $\mathrm{I}_{2}$ & $31,72^{\mathrm{a}}$ \\
4 & $\mathrm{I}_{0}$ & $29,87^{\mathrm{b}}$ \\
\hline
\end{tabular}

Keterangan: Nilai yang diikuti oleh huruf yang sama, menunjukkan tidak berbeda signifikan pada taraf signifikansi $5 \%$.

Tabel 9, menunjukkan bahwa perlakuan lama perendaman memiliki nilai rata-rata yang fluktuatif dengan nilai tertinggi terdapat pada lama perendaman selama $I_{1}$ dengan nilai sebesar $32,97 \%$, dan terendah terdapat pada $I_{0}$ sebesar $29,88 \%$. Lama perendaman $I_{3}$ tidak menunjukkan nilai yang lebih tinggi dari $\mathrm{l}_{1}$. Namun, setelah dilakukan uji lanjut menunjukkan bahwa pada semua lama perendaman tidak berbeda signifikan kecuali pada lama perendaman $\mathrm{I}_{0}$ berbeda signifikan dengan lama perendaman lainnya.

Widyawati et al. (2009) menjelaskan bahwa semakin lama perendaman benih di dalam air dapat meningkatkan kadar air benih. Benih tanpa perendaman memiliki kadar air $26,44 \%$, kemudian semakin meningkat setelah direndam selama 2,5 bulan menjadi $32,12 \%$, begitupun ketika benih berkecambah, kadar air semakin meningkat menjadi $37,09 \%$. Walaupun berdasarkan hasil penelitian secara nilai rata-rata memiliki nilai yang berbeda, namun secara uji lanjut semua lama perendaman tidak berbeda signifikan terkecuali pada $I_{0}$ (tanpa perendaman). Hal ini sejalan dengan penelitian Widyawati et al. (2009) yang menyatakan bahwa benih yang direndam selama 2 jam tidak berbeda signifikan dengan benih yang direndam selama 24 jam, kemudian ketika direndam selama 2 bulan maka kadar air benih meningkat dan hasilnya berbeda signifikan dengan lama perendaman 24 jam. Dengan demikian, lama perendaman dalam penelitian ini masih mempunyai rentang yang kecil untuk mendapatkan hasil yang paling optimal antar perlakuan.

\section{Panjang Embrio}

Sutopo (2012) menjelaskan embrio merupakan suatu tanaman baru yang terjadi dari bersatunya gamet-gamet jantan pada satu proses pembuahan. Embrio yang 
perkembangannya sempurna akan terdiri dari struktur-struktur sebagai berikut: epikotil (calon pucuk), hipokotil (calon akar), dan kotiledon (calon daun).

Tabel 10. Hasil Uji DMRT Pengaruh Tingkat Kemasakan Terhadap Panjang Embrio (mm)

Table 10. Result DMRT on the Effect of Maturity Levels on Embryo Length ( $\mathrm{mm}$ )

\begin{tabular}{ccc}
\hline Ranking & Kode Perlakuan & Nilai Rata-Rata \\
\hline 1 & $\mathrm{k}_{1}$ & $3,92^{\mathrm{a}}$ \\
2 & $\mathrm{k}_{3}$ & $3,87^{\mathrm{a}}$ \\
3 & $\mathrm{k}_{2}$ & $3,35^{\mathrm{b}}$ \\
\hline
\end{tabular}

Keterangan: Nilai yang diikuti oleh huruf yang sama, menunjukkan tidak berbeda signifikan pada taraf signifikansi $5 \%$.

Tabel 10, menunjukkan bahwa panjang embrio pada setiap tingkat kemasakan memiliki nilai rata-rata yang berbeda. Tingkat kemasakan yang mempunyai panjang embrio tertinggi terdapat tingkat kemasakan $\mathrm{k}_{1}(\mathrm{M}-3)$ sebesar $3,92 \mathrm{~mm}$, diikuti oleh $\mathrm{k}_{3}$ sebesar $3,87 \mathrm{~mm}$, sedangkan nilai rata-rata panjang embrio terendah terdapat pada kemasakan $\mathrm{k}_{2}$ sebesar 3,35 mm. Setelah dilakukan uji lanjut DMRT pada taraf signifikansi $5 \%$, perlakuan tingkat kemasakan $\mathrm{k}_{1}$ dan $\mathrm{k}_{3}$ menunjukkan tidak berbeda signifikan, sementara keduanya berbeda signifikan dengan $\mathrm{k}_{2}$.

Tabel 11. Hasil Uji DMRT Pengaruh Bahan Perendaman Terhadap Panjang Embrio (mm) Table 11. Result DMRT on the Effect of Submersion Liquid Substance on Embryo Length $(\mathrm{mm})$

\begin{tabular}{ccc}
\hline Ranking & Kode Perlakuan & Nilai Rata-Rata \\
\hline 1 & $\mathrm{I}_{3}$ & $4,04^{\mathrm{a}}$ \\
2 & $\mathrm{I}_{2}$ & $3,99^{\mathrm{a}}$ \\
3 & $\mathrm{I}_{1}$ & $3,72^{\mathrm{a}}$ \\
4 & $\mathrm{I}_{0}$ & $3,10^{\mathrm{b}}$ \\
\hline
\end{tabular}

Keterangan: Nilai yang diikuti oleh huruf yang sama, menunjukkan tidak berbeda signifikan pada taraf signifikansi $5 \%$.

Tabel 11, menunjukkan bahwa panjang embrio semakin meningkat dengan semakin lamanya jangka waktu perendaman. Nilai tertinggi terdapat pada $\mathrm{I}_{3}$ sebesar $4,04 \mathrm{~mm}$ dan nilai terendah terdapat pada $I_{0}$ sebesar $3,10 \mathrm{~mm}$. Setelah dilakukan uji lanjut dengan uji DMRT menunjukkan bahwa semua lama perendaman tidak berbeda signifikan terkecuali pada $I_{0}$ berbeda signifikan dengan lama perendaman lainnya. Tidak ada perbedaan signifikan antar $I_{1}, I_{2}$, dan $I_{3}$ menunjukkan bahwa interval lama perendaman antar perlakuan masih sedikit. Sehingga menunjukkan pengaruh yang tidak terlalu jauh berbeda antar perlakuan.

\section{KESIMPULAN dan SARAN}

Berdasarkan hasil penelitian menunjukkan bahwa metode perendaman dengan bahan alami tidak dapat mematahkan dormansi benih aren, walaupun jika dilihat dari hasil penelitian menunjukkan pengaruh signifikan pada beberapa parameter, sehingga perlakuan yang diberikan pada penelitian ini tidak dapat digunakan untuk mematahkan dormasi benih aren. Namun demikian, perlunya penelitian lebih lanjut dengan jangka waktu perendaman yang digunakan dengan bahan perendaman yang sama.

\section{DAFTAR PUSTAKA}


[Menper] Menteri Pertanian. (2014). Lampiran Peraturan Menteri Pertanian Republik Indonesia Nomor 133/Permentan/OT.140/12/20134.12011 Tentang Pedoman Budidaya Aren (Arenga pinnata Merr) yang Baik tahun 2013.

Baharuddin dan Taskirawati, I. (2009). Buku Ajar Hasil Hutan Bukan Kayu. Fakultas Kehutanan, Universitas Hasanuddin. Makassar.

Bul. (2017). Provinsi Nusa Tenggara Barat Mulai Ekspor Gula Merah. Suara NTB Jendela NTB untuk Dunia. Mataram. Diakses pada tanggal 5 April 2017. Dari (http://www.suarantb.com/news/2017/01/25/21438/ntb.mulai.ekspor.gula.merah).

Chaerani, N. (2015). Pemecahan Dormansi Aren (Arenga pinnata Merr.) dengan Pengamplasan Biji dan Perendaman Dalam Berbagai Konsentrasi Kalium Nitrat $\left(\mathrm{KNO}_{3}\right)$ [Skripsi]. Program Studi Kehutanan. Universitas Mataram. Mataram.

Ichsan. (2014). Penentuan Konsentrasi Kadar Alkohol dan Asam Asetat dalam Nira Berdasarkan Lama Waktu Penyimpanan Pada Suhu Ruang. Jurnal Kesehatan IImiah Nasuwakes, 7(1), 1-8.

Lempang, M. (2012). Pohon Aren dan Manfaat Produksinya. Jurnal Info Teknis Eboni, 9(1), 37-54.

Lensari, D. (2009). Pengaruh Pematahan Dormansi Terhadap Kemampuan Perkecambahan Benih Angsana (Pterocarpus IndicusWill) [Skripsi]. Departemen Silvikultur Fakultas Kehutanan Institut Pertanian Bogor. Bogor.

Marsiwi, T. (2012). Laporan Seminar Umum Beberapa Cara Perlakuan Benih Aren (Arenga pinnataMerr) Untuk Mematahkan Dormansi. Pemuliaan Tanaman, Jurusan Budidaya Pertanian, Fakultas Pertanian Universitas Gadjah Mada. Yogyakarta.

Mudiana, D. (2006). Perkecambahan Syzygium cumini(L.) Skeels. Germination of Syzygium cumini (L.) Skeels. Jurnal Biodiversitas, 8(1), 39-42.

Rozen, N., Thaib, R., Darfis, I. \& Firdaus. (2016). Pematahan Dormansi Benih Enau (Arenga pinnata) dengan Berbagai Perlakuan Serta Evaluasi Pertumbuhan Bibit di Lapangan. Jurnal Pros Sem Nas Masy Biodiv Indon, 2(1), 27-31.

Suita, E \& Syamsuwida. D. (2015). Peningkatan Daya dan Kecepatan Berkecambah Benih Malapari (Pongamia pinnata). The Enhancement of the rate and capacity of germination of Malapari (Pongamia pinnata) seeds. Balai Penelitian Teknologi Perbenihan Tanaman Hutan. Bogor. 49-59.

Sutopo, L. (2012). Teknologi Benih Edisi Revisi Fakultas Pertanian Universitas Brawijaya. Jakarta: Rajawali Pers.

Usman, M.A. (2006). Pengaruh Tingkat Kemasakan dan Pematahan Dormansi Benih Aren (Arenga pinnata(Wurmb.) Merr.) Pada Kondisi Media yang Berbeda [Skripsi]. Program Studi Pemuliaan Tanaman dan Teknologi Benih Fakultas Pertanian Institut Pertanian Bogor. Bogor.

Widyawati, N., Tohari, Yudono, P. \& Soemardi, I. (2009). Permeabilitas dan Perkecambahan Benih Aren (Arenga pinnata (Wurmb.) Merr.) The Permeability and Germination of Sugar Palm Seeds (Arenga pinnata (Wurmb.) Merr.).J. Agron. Indonesia, 37(2), 152-158.

Yudono, P. (2015). Pembenihan Tanaman Dasar Ilmu, Teknologi dan Pengelolaan. Yogyakarta: Gadjah Mada University Press. 